\title{
Evidence of a water-rich silica gel state during the formation of a simple pegmatite
}

\author{
R. ThOMAS ${ }^{1, *}$ and P. DAVIDSON ${ }^{2}$ \\ 1 German Research Centre for Geosciences GFZ, Telegrafenberg D320, Potsdam, Brandenburg D-14473, Germany \\ 2 ARC Centre of Excellence in Ore Deposits, University of Tasmania, Tasmania, Australia
}

[Received 29 May 2012; Accepted 5 October 2012; Associate Editor: Teal Riley]

\section{ABSTRACT}

This study reports the discovery of inclusions, which are inferred to represent trapped primary silicate gels, in simple pegmatites genetically connected to the Precambrian Rønne granite of Bornholm Island, Denmark. These inclusions are randomly associated with more typical melt and alkali-carbonate-rich and bicarbonate-rich fluid inclusions. Their relationship to the latter and to the formation of the pegmatite bodies is discussed. The silicate gel inclusions become increasingly common towards the quartz cores of the pegmatites, and are considered to demonstrate increasing water and alkali carbonate concentrations in the pegmatite-forming liquid, and an accompanying tendency for sol/gel formation. This discovery may have important implications for the formation of the quartz cores of pegmatites. The possible origin of the alkali-carbonate concentrations in pegmatite-forming fluids is also briefly discussed.

KEYwORDs: Precambrian pegmatites, nahcolite-rich inclusions, silica gel inclusions, origin of alkali carbonate melts, quartz core formation.

\section{Introduction}

Previous studies have noted that there is a compositional gap between silicate melts with $\mathrm{H}_{2} \mathrm{O}$ concentrations of $<10$ wt. $\%$ and hydrothermal fluids with $\mathrm{H}_{2} \mathrm{O}$ concentrations $>90$ wt. $\%$. Experimental work (Veksler and Thomas, 2002; Smirnov et al., 2012) suggests that this compositional space is represented by a continuum of water- and silica-rich phases ranging from very volatile-rich melts, through hydro-colloid suspensions, to very dense hydrothermal fluids. The importance of such colloidal systems is being increasingly recognized. They occur in two basic forms: sols are colloidal systems in which solid particles with dimensions from $\sim 1 \mathrm{~nm}$ to $1 \mu \mathrm{m}$ are dispersed in a liquid medium; and gels are systems in which the colloidal particles form a coherent cross-linked structure that is inter-

* E-mail: rainerthomas@t-online.de

DOI: 10.1180/minmag.2012.076.7.11 penetrated by a liquid (Frondel, 1962 and references therein; Large, 1969; Dörfler, 2002). In this paper we discuss hydro-colloids, which are defined as colloidal systems in which the colloid particles, principally $\mathrm{SiO}_{2}$, are dispersed in water.

With the exception of suggestions by Merritt (1923), Brotzen (1959), Taylor $(2005,2006)$ and Williamson et al. (2002), the possibility that hydrogel might be a transport medium in the formation of pegmatites has been essentially ignored. However, the transport of the silicate component as a hydrogel can be extremely efficient (Dörfler, 2002). The occurrence of gels and sols as important mineral-forming media in nature is well established, as for example in low temperature processes in dispersed clays. However, the recent observation that truly colloidal systems can survive without coagulation in inclusions for more than $100 \mathrm{Ma}$ is surprising (Prokofiev et al., 2008).

Hydrothermal diamond anvil cell (HDAC) experiments (Veksler and Thomas, 2002; 
Thomas et al., 2006, 2011b) have shown that a silicate-gel state can occur in water-rich synthetic fluid systems similar in composition to the primary melt inclusions with type-B characteristics (water-rich peralkaline melts) found in many pegmatites, at relatively high temperatures of $450^{\circ} \mathrm{C}$ (Thomas et al., 2011b: fig 9g). These experiments also show that phase changes, for example coagulation, can be very abrupt over small temperature ranges (see also Large, 1969). Given the experimental evidence for the existence of silica gels and volatile-rich silicate melt inclusions in graphic pegmatites we can reasonably assume that both may coexist at temperatures at or above $600^{\circ} \mathrm{C}$.

Recently, Smirnov et al. (2012) published a study which addressed an intermediate composition, with approximately equimolar $\mathrm{H}_{2} \mathrm{O}$ and $\mathrm{SiO}_{2}$. They showed that at $\mathrm{Na}_{2} \mathrm{O}$ concentrations $>2$ wt. $\%$ a water- and a silica-rich phase, referred to as a hydrosilicate liquid (HSL), with colloidal properties, developed from water- and alkali-rich silicate melts at $\sim 600^{\circ} \mathrm{C}$ and remained relatively stable to low temperatures. The quantity of HSL produced was proportional to the $\mathrm{Na}_{2} \mathrm{O}$ concentration, and was unaffected by either $\mathrm{NaCl}$ or $\mathrm{HF}$ contents. The HSL was shown to be capable of dissolving high but unquantified amounts of $\mathrm{Ta}$, and by inference may be important in the transport of other elements.

In recent years there has been a revival of the idea that pegmatites can be formed via crystallization from hydrous silicate gels (e.g. Wilkinson et al., 1996; Williamson et al., 2002). One contentious problem in pegmatite genesis is the common presence of massive almost monomineralic quartz cores, which indicates the deposition of very large amounts of $\mathrm{SiO}_{2}$ with almost no other solid phases. If the typical solubility of quartz in hydrothermal solutions is used to explain the presence of this quartz, a mass balance problem emerges, as a very large amount of water is required to produce the deposit. This is inconsistent with the generally limited evidence for hydrothermal fluid flow through, or out of, most pegmatites. Brotzen (1959) discussed water-rich silica gel as a possible medium for $\mathrm{SiO}_{2}$ transport in answer to this problem. Although there are difficulties with models that propose gels as the principal mechanism for pegmatite formation, the sol/gel state may provide an alternative explanation for some specific aspects of pegmatite development. Thomas and Davidson (2008) suggested that a gel state as the final melt stage after everything else has crystallized is indeed a possibility, and this suggestion is supported by the recent observation of the presence of well crystallized topaz, apatite and other minerals preserved in blue chalcedony from the Otjozaharun pegmatite near Otjiwarongo, Namibia (Thomas et al., 2012).

As a working hypothesis, Brotzen (1959) considered the gel state as important for the development of giant crystals in the core-margin association, although at the time, direct experimental evidence was lacking. The recently observed alkali-rich fluid or melt inclusions in quartz support this hypothesis, as the formation of a silica gel is favoured in strongly alkaline fluids (Large, 1969).

Silica gels can be highly effective ion-exchange media which can produce extreme enrichment of some trace elements. For example, the occurrence of the mineral hafnon adjacent to the quartz core of the Naipa and Muiane pegmatites in Mozambique (Correia Neves and Lopes Nunes, 1974) requires a very effective process of selective element enrichment to produce the 'inverse' elemental arrangement required to form hafnon, in which $\mathrm{Hf}$ is the main element and $\mathrm{Zr}$ is present only in traces.

From experiments and observations on natural inclusions in minerals, the rheological properties of the gels vary from more viscous or elastic liquids to those with quasi-solid characteristics. The transitions between a fluid and a quasi-solid material depend among other variables on the water content, temperature and the time-dependent change in viscosity during flow (thixotropic behaviour) (Dörfler, 2002).

Although experimental evidence shows that water-rich silica gel phases can occur, their existence and abundance in nature remains controversial. As they are structurally disordered they tend to alter over time into ordered silica or aluminosilicate minerals, or to more stable disordered aqueous solutions. Even if they are trapped as inclusions within stable phases their survival is not guaranteed. The research described here is a continuation of the study of the Rønne pegmatites presented by Thomas et al. (2011b). We describe the occurrence of inclusions in quartz and feldspar from samples representative of the quartz core of the pegmatite, which have trapped a silicate hydrogel phase. These inclusions resemble the fluid inclusions found in low temperature chalcedony or agate amygdales by Khakimov (1968) and Prokofiev et al. (2008). 
Figure 1 is a schematic diagram of typical inclusions in geodes in chalcedony veins, which resemble the inclusions we describe from the quartz of the Rønne pegmatite. We also discuss the post-trapping processes that have brought these inclusions to their current state, and the possible significance of silicate hydrogel phases in the origin and evolution of pegmatites.

\section{Sample description}

\section{The host rock: the Rønne granodiorite}

The Rønne granodiorite at the Klippeløkkene quarry is the most mafic of all the Bornholm granitoids. It is a massive, medium-grained, melanocratic and deformation-free rock containing (vol.\%): potassium feldspar (29\%); plagioclase $(30 \%)$; quartz $(21 \%)$; hornblende $(10 \%)$; biotite $(5 \%)$; and minor amounts of titanium-rich magnetite; titanite; calcite (found during the present Raman study); apatite; and zircon (5\%) (Noe-Nygaard, 1963, Zariņš and Johannson, 2009). Pyroxenes of the enstatiteferrosilite series and diopside are locally present. The anorthite contents of the cores and rims of the plagioclase are 35-40 mol. \% and 15-20 mol.\%, respectively. Fresh well preserved potassium feldspar contains about $5000 \mathrm{ppm} \mathrm{Ba}$ (Noe-Nygaard, 1963). The rock contains at least two types of zircon: short prismatic crystals with an aspect ratio between about 1.3 and 2.5; and younger, highly elongated prismatic crystals with aspect ratios between about 25 and 50 . Emeleusite, $\mathrm{Na}_{4} \mathrm{Li}_{2} \mathrm{Fe}_{2}^{3+} \mathrm{Si}_{12} \mathrm{O}_{30}$, occurs as a rare accessory phase as $40 \times 80 \mu \mathrm{m}$ crystals. The fresh Rønne granites are characterized by feldspars which contain numerous calcite crystals, up to $1000 \mu \mathrm{m}$ in size, with no evidence for a secondary origin. This implies that the primary graniteforming magmas were carbonate-bearing.

The best age estimate for the Rønne granodiorite is $1459 \pm 4 \mathrm{Ma}$ by $\mathrm{U}-\mathrm{Pb}$ geochronology (Zariņš and Johannson, 2009). This agrees (within error) with the concordia age of $1456 \pm 5 \mathrm{Ma}$ reported by Waight et al. (2012). The presence of pyroxene relicts indicates relatively dry crystallization conditions, and is also consistent with the lowest water content of melt inclusions in quartz of all Bornholm granitoids (3.2 wt.\%), and the extrapolated high solidus temperature of $742^{\circ} \mathrm{C}$ (Thomas, 1994). According to data reported by Noe-Nygaard (1963) the rock has an aluminium saturation index (ASI) of 0.838, and in the pegmatite contact zone the granite has a $\mathrm{CO}_{2}$ content of 0.59 wt. $\%$, corresponding to a carbonate concentration of 0.76 wt.\%. Away from the pegmatites the granite is carbonatefree, or carbonate is below the detection limit.

\section{The Rønne pegmatites}

The granodiorite from Rønne contains abundant sub-horizontal and swarms of subparallel vertical dilatational pegmatite veins with near parallel walls and thicknesses varying from centimetres to more than a metre; they are rarely less than $10 \mathrm{~m}$ long (Micheelsen, 1960; Jøgart, 2001). The very fresh flesh-coloured pegmatite is a simple abyssal

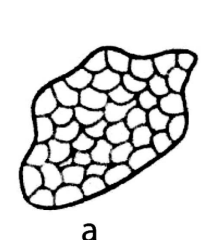

a

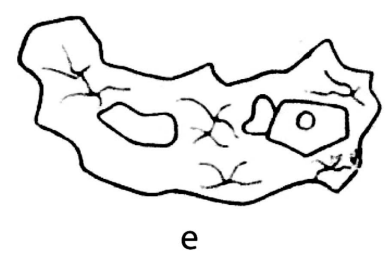



b

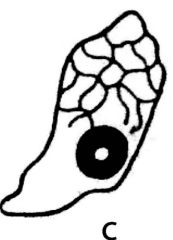

C

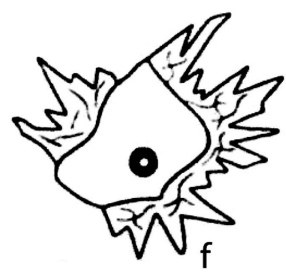

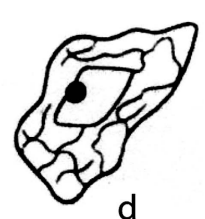

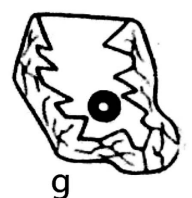

Fig. 1. Genetic types of inclusions in geodes of chalcedony-quartz veins modified from a sketch in Khakimov (1968). The inclusions $a$ and $b$ represent true colloid inclusions, $c$ and $d$ mixed colloid-water inclusions and in inclusions $e, f$ and $g$ there are larger volumes of aqueous solutions. 


\section{R. THOMAS AND P. DAVIDSON}

quartz-feldspar pegmatite with a conspicuous graphic texture and only minor amounts of mica (Fig. 2). The microcline perthite is graphically intergrown with quartz and contains $50-300 \mathrm{ppm}$ $\mathrm{Ba}$. None of the Rønne pegmatites contain miarolitic cavities.

The Rønne pegmatites are zoned, typically having sharp contacts between the country rock and a fine-grained graphic-textured zone (between
A and B in Fig. 2a). This zone is primarily graphic-textured flesh-coloured microcline perthite, and also contains irregular pale patches of albite $\left(\mathrm{An}_{8}-\mathrm{An}_{10}\right)$ and minor yellowish hyalophane $\left[(\mathrm{K}, \mathrm{Ba}) \mathrm{Al}(\mathrm{Si}, \mathrm{Al})_{3} \mathrm{O}_{8}\right]$ (Fig. $2 a$ ). The transition from the relatively fine-grained outer zone to the core-margin zone (between B and the central quartz aggregates of Fig. $2 a$ ) is marked by a significant increase in grain size, producing a
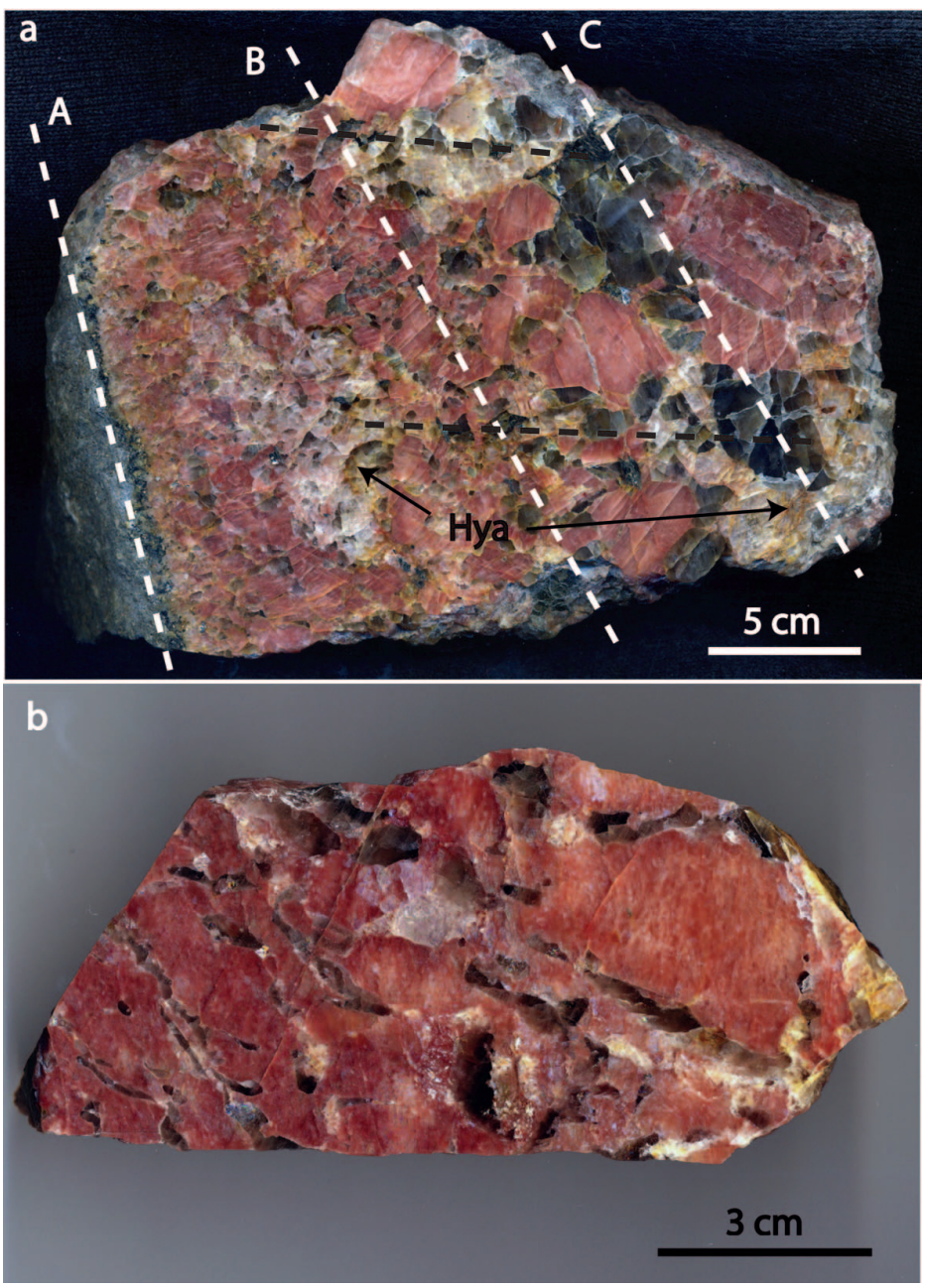

FIG. 2. (a) A section of a sub-horizontal pegmatite vein from the Rønne granite, Bornholm Island, Denmark. The line $\mathrm{A}$ indicates the footwall contact of the pegmatite with the granite; graphic granite is present between $\mathrm{A}$ and $\mathrm{B}$; and $\mathrm{C}$ is the centre of the vein with large smoky quartz crystals in a compact quartz core. The irregular pale area between $\mathrm{A}$ and $\mathrm{B}$ contains albite and hyalophane $\left[(\mathrm{K}, \mathrm{Ba}) \mathrm{Al}(\mathrm{Si}, \mathrm{Al})_{3} \mathrm{O}_{8}\right]$ (Hya, arrowed). The horizontal dotted black lines show the axes of the channels of finer-grained material starting in the graphic zone and ending in the quartz core. (b) A polished specimen from the graphic granite zone containing flesh-coloured microcline and small isolated smoky quartz rods. 
coarse pegmatitic texture. In addition to the graphic texture the large K-feldspar crystal aggregates are commonly rimmed by quartz borders up to $3 \mathrm{~mm}$ wide (Fig. $2 b$ ). The grain size of the near-black smoky quartz increases from $<1 \times 10 \mathrm{~mm}$ at the pegmatite rim, to more than $5 \times 4 \mathrm{~cm}$ in the centre of the pegmatite vein (line $\mathrm{C}$ in Fig. 2a), which is distinguished by large smoky quartz aggregates. Although these aggregates are not continuous, because of the generally small size of the veins, they can be considered to represent a discontinuous quartz core. Figure $2 a$ shows the graphic zone, a diffuse zone containing mainly albite. A channel-like connection to the large smoky quartz aggregates in the centre of the vein starts in this zone and is arranged in a repetitive pattern. Rutile, apatite, zircon and calcite, graphite, magnetite, ilmenite, pyrite and chalcopyrite occur as accessory phases. Christensen and Zimmerman (2004) have also described relatively large (up to $2 \times 2 \times 5 \mathrm{~cm}$ ) prismatic crystals of allanite-(Ce).

In a thick section the graphic granite is seen to contain graphite aggregates, in some cases up to $5 \times 1 \mathrm{~mm}$ in size, covering $\sim 1.5 \%$ of the surface and extending throughout the whole sample (Fig. 3b). Raman spectrometry revealed a peakarea graphite crystallinity index, R2, of 0.062 . According to Beyssac et al. (2002), this value is equivalent to a crystallization temperature of $\sim 700^{\circ} \mathrm{C}$. Together with our determinations (Thomas et al., 2011b), this indicates a range of 700 to $550^{\circ} \mathrm{C}$ for the main stages of pegmatite formation. Quartz and some feldspars are
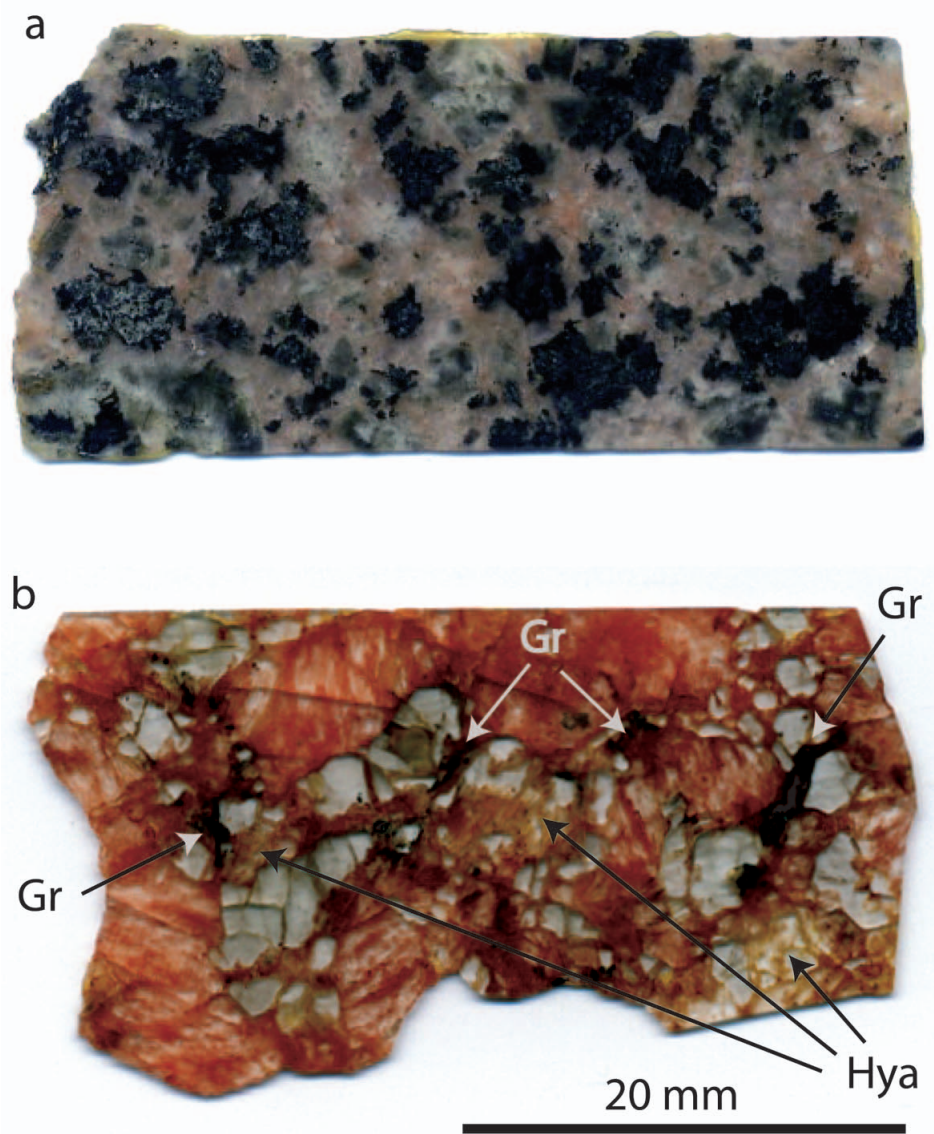

FIG. 3. Thick sections of $(a)$ the Rønne granite and $(b)$ pegmatite, containing mainly feldspars and quartz. The black patches in $(b)$ are graphite $(\mathrm{Gr})$ aggregates. Hya $=$ hyalophane. 
characterized by different inclusion types including rare silicate melt inclusions; nahcoliterich and other carbonate/bicarbonate-bearing fluid inclusions (Thomas et al., 2011b); and 'gel-like' inclusions, which are described below. Some quartz crystals contain all of the described primary inclusion types at a density of up to about $1.4 \times 10^{7}$ per $\mathrm{cm}^{3}$ (Thomas et al., 2011b)

\section{Micro-Raman spectroscopy}

During petrographic study of double-polished $500 \mu \mathrm{m}$ thick sections from the Rønne pegmatite, many nahcolite-rich fluid inclusions were found in the quartz, at grain boundaries between different minerals, and as isolated inclusions in all of the main phases. As the identification of the very small carbonate and bicarbonate daughter mineral phases is difficult by optical microscopy we have used high-resolution micro-Raman spectroscopy for their characterization.

Raman spectra were recorded using a JobinYvon LabRam HR800 spectrometer (grating: 1800 lines/mm), coupled to an Olympus optical microscope with a long-working-distance LMPlanFl $100 \times / 0.80$ objective. We used the 514 and $488 \mathrm{~nm}$ excitation lines of a coherent $\mathrm{Ar}^{+}$Innova 70C laser, operating at a power of $300 \mathrm{~mW}$ (corresponding to $\sim 14 \mathrm{~mW}$ at the sample), with a spectral resolution of $\leqslant 0.6 \mathrm{~cm}^{-1}$. Each unpolarized spectrum was constructed from six acquisitions of $10 \mathrm{~s}$ each. The spectra were collected at a laboratory temperature of $20^{\circ} \mathrm{C}$ using a Peltiercooled CCD detector; the positions of the Raman bands were corrected using the principal plasma lines of the argon laser as a reference. The divergence between the published and measured positions of the plasma lines is no greater than $0.6 \mathrm{~cm}^{-1}$. If the inclusion geometry was suitable, the percentage volume occupied was estimated.

The main Raman bands for typical carbonates and bicarbonates in fluid and melt inclusions are listed in table 1 of Thomas et al. $(2011 a, b)$. For nahcolite $\left(\mathrm{NaHCO}_{3}\right)$; zabuyelite $\left(\mathrm{Li}_{2} \mathrm{CO}_{3}\right)$; and calcite $\left(\mathrm{CaCO}_{3}\right)$ the diagnostic bands centred at $1045 \mathrm{~cm}^{-1}$; 95 and $1090 \mathrm{~cm}^{-1}$; and $1085 \mathrm{~cm}^{-1}$, respectively.

\section{Results}

\section{Description and characteristics of gel inclusions in the Rønne pegmatite}

The term 'gel inclusion' is used here to describe inclusions which consist mainly of microcrystal- line quartz grains with minor amounts of other phases (Fe-oxides/hydroxides, carbonates). We propose that these formed by post-trapping accretive crystallization from the original gel state during declining $P-T$ conditions. As the sol or gel state is thermodynamically unstable, more stable polymorphs (e.g. $\beta$-quartz, cristobalite and mogánite) form over time by syneresis and phase transformation.

Gel inclusions resemble fluid inclusions, they commonly contain a small shrinkage vapour bubble (Figs 1 and 4), but unlike fluid inclusions contain a large volume ( $\sim 50$ to 100 vol. $\%$ ) of solid material. This occurs principally as a fine-grained granular filling of micrometre-sized ( 0.5 to $1.5 \mu \mathrm{m})$ grains, primarily quartz, which forms regular grains and accretions of such grains merged into irregular clusters. These inclusions typically contain small but variable quantities of feldspar, more rarely $\mathrm{FeOOH}$, and possible cristobalite. The remainder of the inclusion is filled with an alkali-carbonate-bearing aqueous solution, and commonly contains a vapour bubble. In a few larger inclusions, daughter crystals with sizes $>5 \mu \mathrm{m}$ (quartz, feldspar, calcite) occur; probably resulting from to post-trapping accretive crystallization and Ostwald ripening.

The inclusions typically range from $\sim 10 \mu \mathrm{m}$ to more than $100 \mu \mathrm{m}$ across, and are rarely more than $500 \mu \mathrm{m}$. They are characterized by a prominent pseudo-granular texture (Fig. $4 a-f$ ). Near the bubbles and commonly at the phase boundaries with the host quartz or feldspar there are irregular patchy areas with aqueous solutions.

Small but significant numbers of calcite and nahcolite crystals in the inclusions indicate the presence of carbonate in the originally pegmatiteforming liquid. However, there are striking differences between such inclusions in quartz and feldspar host crystals. Nahcolite is the dominant carbonate phase in quartz, whereas calcite is the dominant carbonate phase in feldspar, probably because of reaction with calcium in the feldspar. In feldspars, the inclusions are commonly crystallographicallyoriented (Fig. $5 a-c$ ) and very flat, making Raman spectroscopic studies difficult.

Quartz from the graphic zone contains flat former gel inclusions, characterized by quartz aggregates suspended in an aqueous solution with a slightly different orientation to the surrounding quartz (Fig. 6). It is commonly the case that the inclusion can only be seen as a result of this 'disorientation'. There is a clear difference in the 

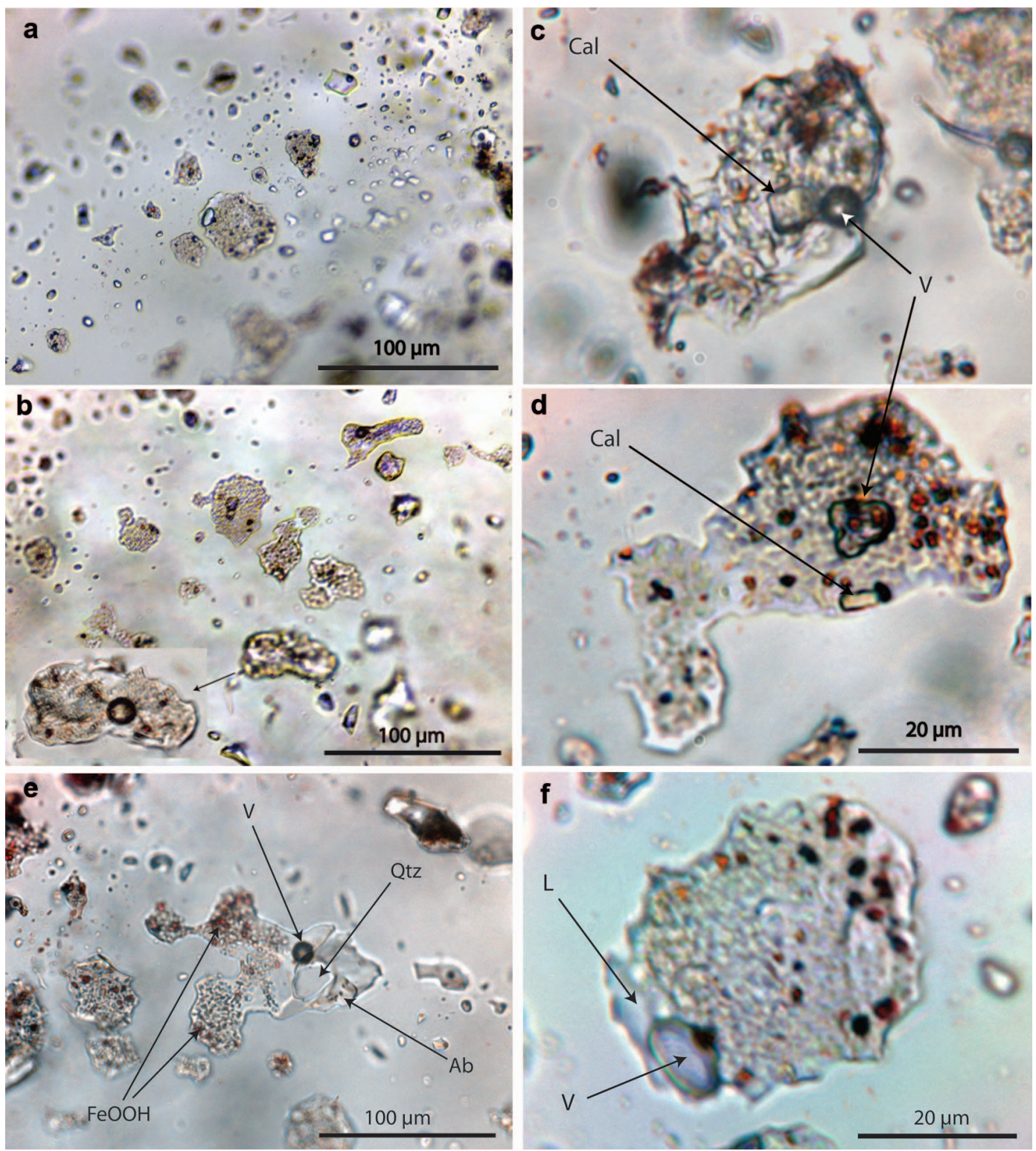

FIG. 4. Typical gel inclusions $(a-e)$ in quartz from the Rønne pegmatite from the quartz core. $(c, d)$ Larger crystals of calcite with granular quartz and dark $\mathrm{FeOOH}$. The inclusion in the centre of $(e)$ contains a larger quartz crystal. $(f) \mathrm{A}$ former gel inclusion in which the grain boundaries are indistinct and appear to merge. Abbreviations are as follows:

$\mathrm{Ab}$, albite; Cal, calcite; $\mathrm{FeOOH}$, goethite; V, vapour; L, aqueous solution.

Raman spectra of the quartz that has crystallized from a melt or solution and the quartz that has crystallized from the gel state (Fig. 7).

Preliminary Raman spectrometry on gel inclusions shows that the $\mathrm{SiO}_{2}$-dominated phases contain significant amounts of molecular water, as indicated by a broad and near-symmetrical Raman band at $\sim 3440 \mathrm{~cm}^{-1}$. From the integrated intensity an approximate estimation of the water concentration of $12.4 \pm 0.7$ wt. $\%$ was calculated 


\section{R. THOMAS AND P. DAVIDSON}
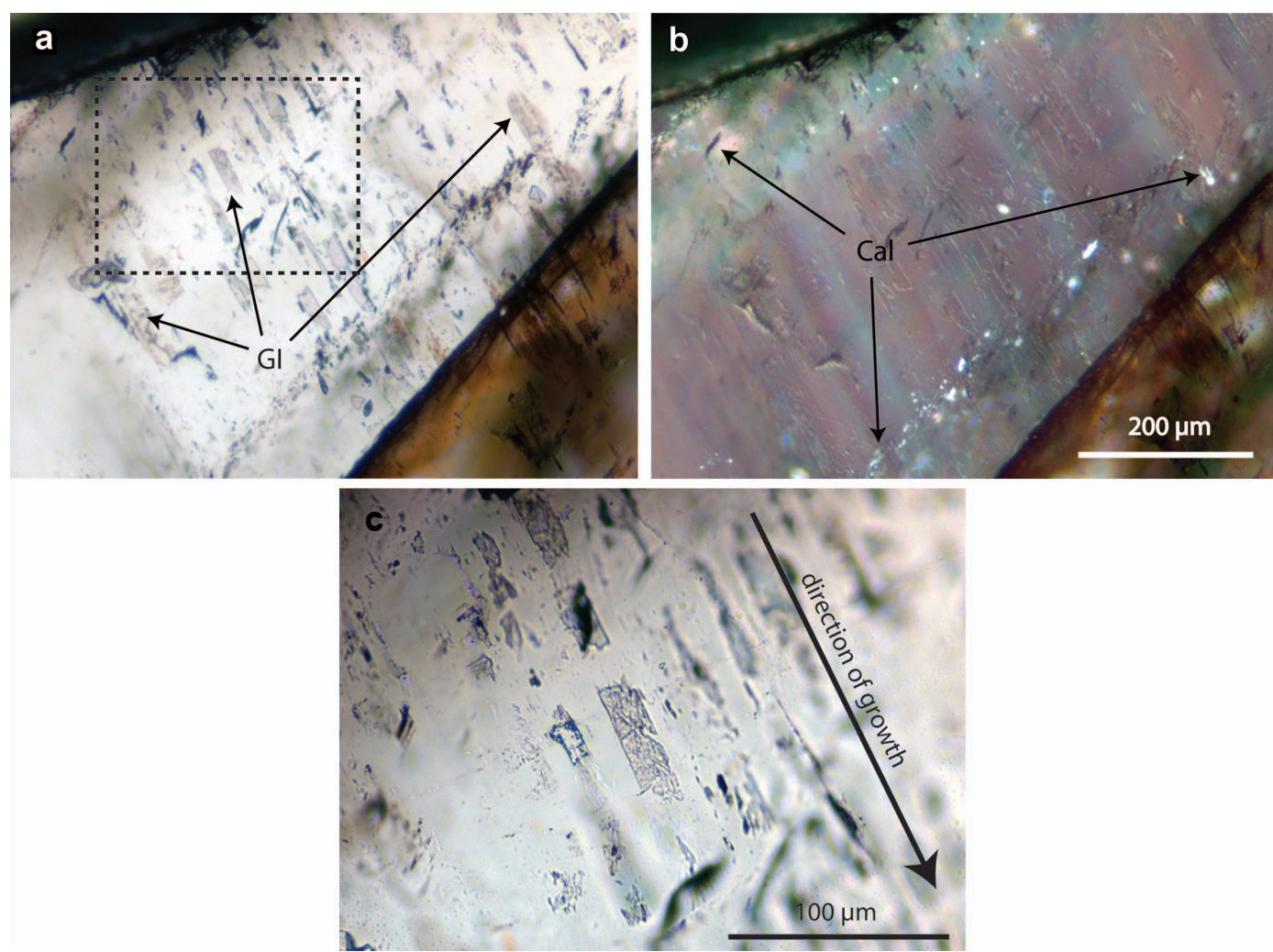

FIG. 5. Gel inclusions in plagioclase from the Rønne pegmatite $(a)$ in plane polarized light, and $(b)$ between crossed polarizers, showing the calcite (Cal) crystals perpendicular to the growth direction. (c) A higher magnification image of the area outlined in $(a)$, showing the oriented arrangement of the inclusions.
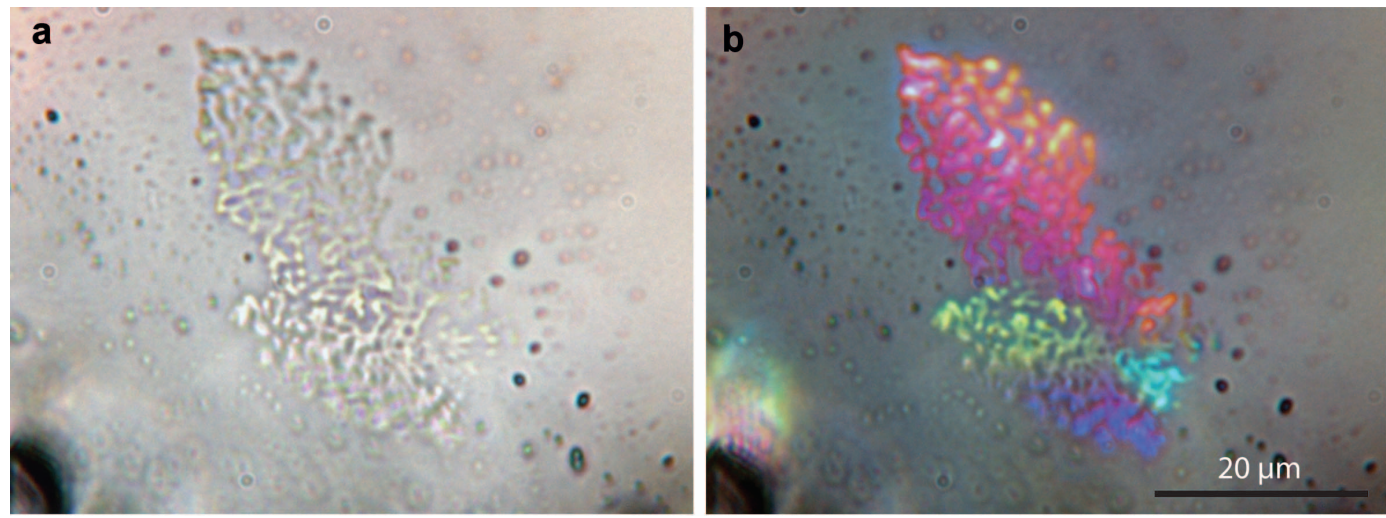

FIG. 6. Inclusion quartz which is interpreted as having formed as a result of crystallization of the gel within crystalline host quartz $(a)$ in transmitted light, $(b)$ between crossed polarizers. Note the small difference in interference colours produced by the wedge-like orientation of the quartz particles in the inclusion. 
from 13 determinations. This value is very high in comparison to the estimated water content of igneous, hydrothermal and metamorphic quartz (Müller and Koch-Müller, 2009; Thomas et al.,
2008, 2009); natural quartz mostly has values less than $300 \mathrm{ppm}$. The ratio between sample and standard integral intensity $\left(8.06\right.$ wt. $\left.\% \mathrm{H}_{2} \mathrm{O}\right)$ is 1.54 (Thomas et al., 2008). An added Raman
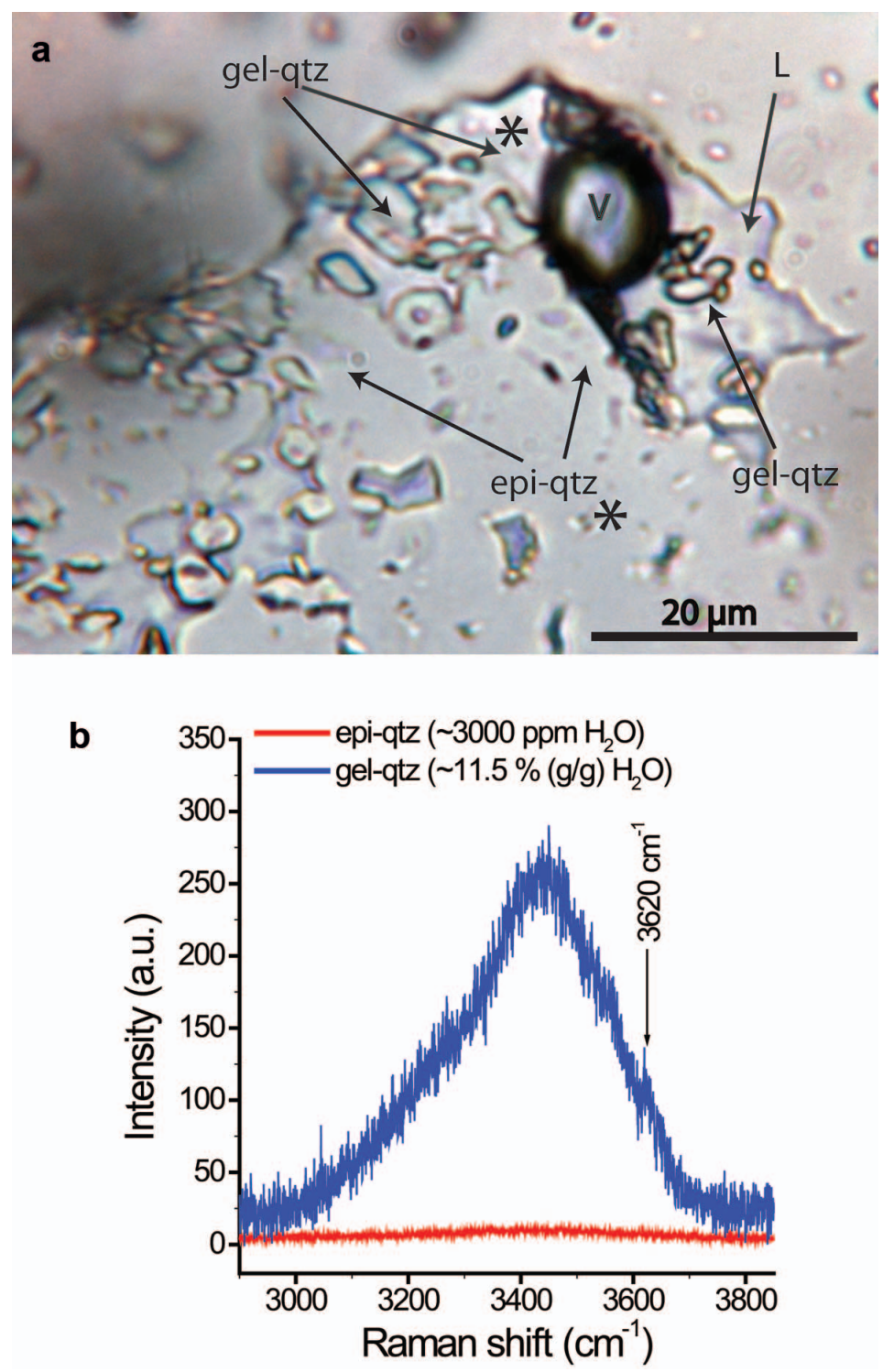

Fig. 7. (a) A large gel inclusion showing more advanced maturation, with some silica converted to euhedral quartz crystals which epitaxially overgrow the host quartz. Abbreviations are as follows: L, aqueous solution; V, vapour; and gel-qtz, newly formed quartz [single euhedral daughter crystals and some partially connected by epitaxial growth to the host quartz (epi-qtz)]. (b) Raman spectra in the high-wavenumber range of the host quartz (epi-qtz) with about 3000 ppm $\mathrm{H}_{2} \mathrm{O}$ and former gel quartz (gel-qtz) containing about $11.5 \mathrm{wt} . \% \mathrm{H}_{2} \mathrm{O}$. The weak band at 3620 $\mathrm{cm}^{-1}$ corresponds to small amounts of $\mathrm{NaOH}$ in the gel quartz (according to Walrafen and Douglas, 2006). The stars show the measuring positions. 
band at $3625 \mathrm{~cm}^{-1}$ suggests that $\mathrm{NaOH}$ is present in significant amounts (Walrafen and Douglas, 2006). A typical total water content for whole inclusions is not given, as the values vary from inclusion to inclusion within a wide range (shown schematically in Fig. 1). The Raman spectrum of the post-trapping gel-quartz differs from that of the crystalline host quartz in the presence of a single and strong band at $1081 \mathrm{~cm}^{-1}$ and a very weak band at $1156 \mathrm{~cm}^{-1}$. The crystalline host quartz has two weak bands at 1064 and $1080 \mathrm{~cm}^{-1}$ and a stronger band at $1158 \mathrm{~cm}^{-1}$ in this spectral range. Furthermore, the Raman spectrum of some post-trapping silica includes a distinct band at $502 \mathrm{~cm}^{-1}$, corresponding to the monoclinic silica polymorph mogánite (Kingma and Hemley, 1994), which is a typical component of silica formed in alkaline fluids (Götze et al., 1998). These Raman data are preliminary and further studies are being conducted. The Raman study of the very small silica aggregates in the former gel inclusions in quartz is rendered difficult by the overwhelming intensity of the host spectra. Better spectra can be obtained from inclusions in other minerals, such as beryl or topaz (Thomas and Davidson, 2008).

During heating on a microscope heating stage, the vapour bubble, if present, disappears, generally at moderate temperatures $\left(100-250^{\circ} \mathrm{C}\right)$. The quartz and possible cristobalite grains show no changes during heating. Due to the very high quartz content of this inclusion type, melting to a glass does not occur in a realistic temperature range $\left(<750^{\circ} \mathrm{C}\right)$, i.e. typical for the trapping temperatures of the melt inclusions. Nonetheless, we interpret these as crystals which have formed in a colloid by ageing of a primary gel (Large, 1969). The gel inclusions have been irreversibly altered in this process.

In the former gel inclusions the concentration of alkali carbonates is at least an order of magnitude less than in the nahcolite- and zabuyelite-bearing fluid or melt inclusions (Thomas et al., 2011b). This implies that the process of sol/gel formation is connected with an effective separation of colloidal $\mathrm{SiO}_{2}$ from the alkali ions, which is further amplified by the crystallization of albite.

\section{Discussion and interpretation}

If water-rich silica gel is present in pegmatitic systems, direct evidence of its existence should be preserved in pegmatites as inclusions.
Recrystallization processes can irreversibly alter such inclusions. Silica-rich hydrocolloids can be irreversibly altered as the temperature falls, into more stable phases such as quartz, and they may also be affected by the destruction of the gel network stabilizers and flocculation by destabilizing of colloidal dispersions. Presumably such processes would also eliminate the gel inclusions in the high temperature stages of pegmatite evolution. However, gel-like inclusions have been found in some quartz, K-feldspar and plagioclase crystals. The identification of this type of inclusions is difficult (Fig. $4 a-e$ ), but we have identified large numbers of such inclusions in the quartz cores of several pegmatites worldwide (Thomas et al., 2012).

We infer a magmatic origin for the alkalicarbonate-rich inclusions, including the gel inclusions, on the basis of the following observations: (1) the dissolution of large amounts of nahcolite in water and $\mathrm{CO}_{2}$-rich solutions is only possible at high temperatures; (2) nahcolite- or carbonate-rich rocks are absent in the neighbourhood of the granites and pegmatites; (3) there are no plausible mechanisms for the strong enrichment of alkali carbonates at low temperatures; (4) the corrosion of feldspars by an alkali carbonate- and $\mathrm{SiO}_{2}$-rich melt or solution implies high temperature reactions; (5) the coexistence of three types of inclusions (silicate-melt inclusions, nahcolite- $\mathrm{SiO}_{2}$-rich inclusions (Fig. 8a), nahcolite-rich $\mathrm{CO}_{2}$ inclusions) is a clearly magmatic phenomenon; (6) the progressive enrichment of $\mathrm{Li}$ as $\mathrm{Li}_{2} \mathrm{CO}_{3}$ (zabuyelite) together with $\mathrm{NaHCO}_{3}$ (Fig. 8b) during the pegmatite evolution from the outer rim towards the quartz core is a clear indication of a process connected with pegmatite formation.

Stable isotope studies are required to prove conclusively whether such fluids are directly genetically connected to the granitic host, or have a deeper source. However such studies would not be simple because of the small mass of the inclusion systems.

The presence of inclusions with extremely high concentrations of nahcolite in quartz, and of calcite as inclusions in plagioclase might be related to the same source. According to Thomas et al. (2011b) the formation of nahcolite from an alkali carbonate-rich aluminosilicate melt can be represented by the following reaction:

Carbonate-rich silicate melt fraction $\rightarrow$

$\mathrm{Na}_{2} \mathrm{Si}_{2} \mathrm{O}_{5}+2 \mathrm{CO}_{2}+\mathrm{H}_{2} \mathrm{O} \rightarrow 2 \mathrm{NaHCO}_{3}+\mathrm{SiO}_{2}$ 

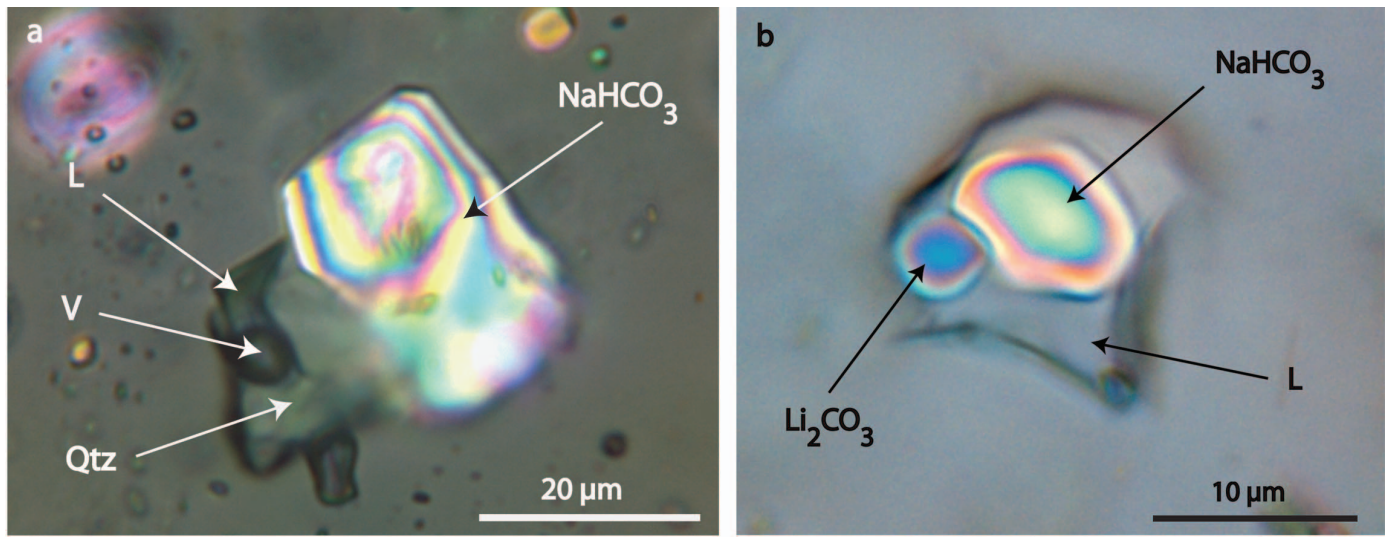

FIG. 8. Typical carbonate-rich inclusions in quartz of the Rønne pegmatite. (a) Early stage inclusion trapped in the graphic granite zone containing nahcolite, quartz and an aqueous solution with a vapour bubble. $(b)$ Late stage trapped inclusion in the transition zone between graphic granite and the quartz core. Abbreviations are as follows: $\mathrm{L}$, aqueous solution; V, vapour bubble; Qtz, quartz; $\mathrm{NaHCO}_{3}$, nahcolite; $\mathrm{Li}_{2} \mathrm{CO}_{3}$, zabuyelite.

The $\mathrm{Na}_{2} \mathrm{CO}_{3}$ in the solution reacts with plagioclase according to the simplified equation:

$$
\begin{array}{r}
\mathrm{CaAl}_{2} \mathrm{Si}_{2} \mathrm{O}_{8}+\mathrm{Na}_{2} \mathrm{CO}_{3}+4 \mathrm{SiO}_{2} \rightarrow \\
2 \mathrm{NaAlSi}_{3} \mathrm{O}_{8}+\mathrm{CaCO}_{3} .
\end{array}
$$

The $\mathrm{SiO}_{2}$ and albite components, respectively, may then crystallize on the inclusion wall producing even more apparently nahcolite- or calcite-rich inclusions, in some cases containing up to $60 \%$ nahcolite (Thomas et al., 2011b; Thomas and Davidson, 2012b). Such high carbonate concentrations in inclusions in a granite-pegmatite system would previously have been considered unusual, as such high values have only been described from carbonatites (Rankin and Le Bas, 1974a,b).

Hydrothermal diamond anvil cell (HDAC) experiments (Thomas et al., 2011b) show that at temperatures $>500^{\circ} \mathrm{C}, \mathrm{Na}_{2} \mathrm{CO}_{3}$-rich aqueous solutions are very reactive and can dissolve considerable amounts of $\mathrm{SiO}_{2}$. These experiments have also shown the formation of a gel-like state with a relatively high packing density over a limited temperature interval $\left(\sim 448^{\circ} \mathrm{C}\right)$ (Fig. $9 a$ ). During HDAC experiments in the system quartz-sodium disilicate-nahcolite-water, a metastable suspension-like hydrated melt phase (Fig. 9b) formed suddenly at $630^{\circ} \mathrm{C}$ during cooling from a primary homogeneous water-rich melt system at $650^{\circ} \mathrm{C}$ (Veksler et al., 2002; Veksler and Thomas, 2002).

In addition to gel inclusions trapped at high temperature there are also some unusual inclu- sions in plagioclase crystals with a high $\mathrm{OH}^{-}$ contents. From Raman spectroscopy these correspond to an equivalent of $4.8 \pm 1.3$ wt.\% $\mathrm{H}_{2} \mathrm{O}$ (Thomas et al., 2008).

The reactivity of the peralkaline fluid can be determined from the reaction rims of newlyformed quartz at the contact with the feldspars, decorated by many small calcite crystals and nahcolite-rich fluid inclusions in the same quartz and feldspars (Fig. 10). The fluid inclusions in quartz contain mainly nahcolite, and all of the bright areas in plagioclase (Fig. 10) are crystals of calcite concentrated at the boundary zone between quartz and plagioclase. Rare fluid inclusions in plagioclase contain nahcolite and calcite daughter crystals. In the early stage of pegmatite formation the alkali concentration increases to very high values promoting the formation of hydrocolloids of silica.

In large quartz crystals from the centre of the pegmatite veins we found a greater number of inclusions, mainly containing small quartz grains which are similar to the gel inclusions in tourmaline (var. achroite) from Malkhan/ Transbaikalia (Thomas and Davidson, 2008) and to gel inclusions in the agate amygdales and veins described by Khakimov (1968). This suggests that the crystallization of achroitic tourmaline and quartz at a late stage of the pegmatite formation occurs from an alkaline water- and $\mathrm{SiO}_{2}$-rich fluid, probably from a silica sol system. However, we have also found such gel inclusions in the 


\section{R. THOMAS AND P. DAVIDSON}
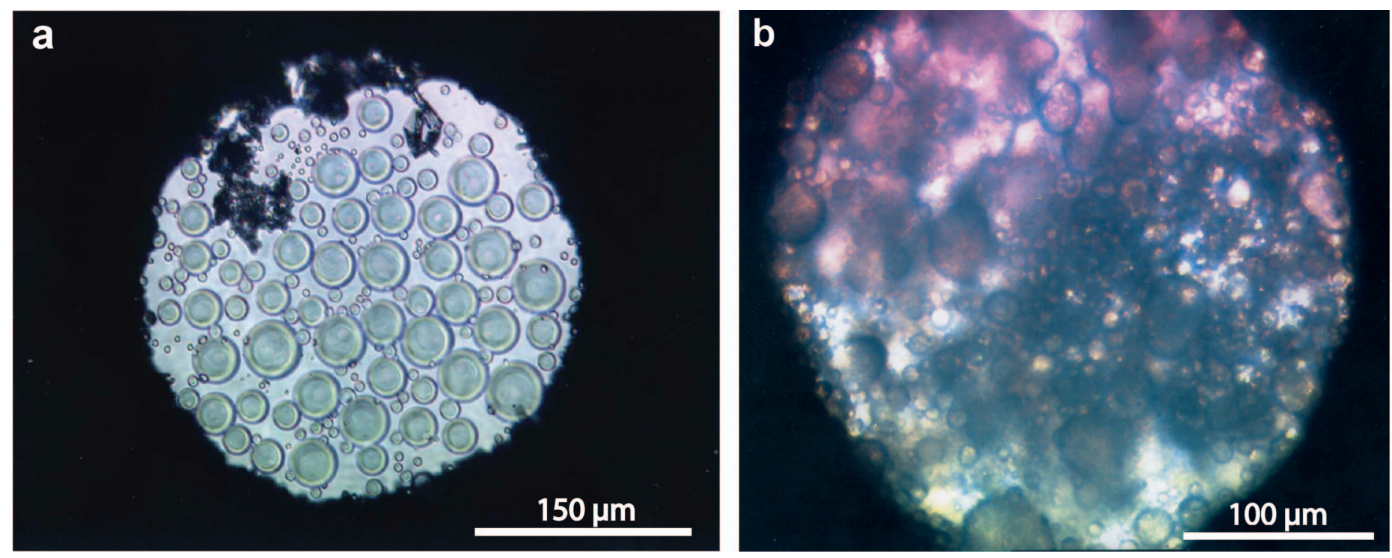

FIG. 9. (a) Photomicrograph from a series taken during a $\mathrm{HDAC}$ experiment in the $\mathrm{SiO}_{2}-\mathrm{NaHCO}_{3}-\mathrm{H}_{2} \mathrm{O}-\mathrm{CO}_{2}$ system at $448^{\circ} \mathrm{C}$ (Thomas et al. $2011 \mathrm{~b}$ ). At this temperature the homogeneous solution suddenly separates into a suspension of a gel-like substance completely filling the chamber formed by the two diamonds and the Re gasket. On further cooling the platelets disappear completely at $430^{\circ} \mathrm{C}$. (b) Formation of a metastable suspension-like hydrated melt phase suddenly at $630^{\circ} \mathrm{C}$ during rapid cooling from $650^{\circ} \mathrm{C}$. At $650^{\circ} \mathrm{C}$ the system was a homogeneous water-rich melt system.

graphic quartz and feldspars which form at the beginning of pegmatite crystallization. Similar inclusions were found also in the root zone of smoky quartz crystals from miarolitic pegmatites in the Königshain granite. All these observations demonstrate that the water content during the pegmatite formation is very high at the beginning of crystallization and increases over time (Thomas and Davidson, 2012a).
Why is the formation of silica sols and gels at high temperatures possible?

Thomas et al. (2011b) have shown that the quartz in the Rønne pegmatite is characterized by fluid inclusions that are very rich in nahcolite $\left(\mathrm{NaHCO}_{3}\right)$ and zabuyelite $\left(\mathrm{Li}_{2} \mathrm{CO}_{3}\right)$. A large percentage of these fluid inclusions contain between 60 and 80 vol.\% of alkali carbonates (Fig. 8). We interpret these fluid inclusions as

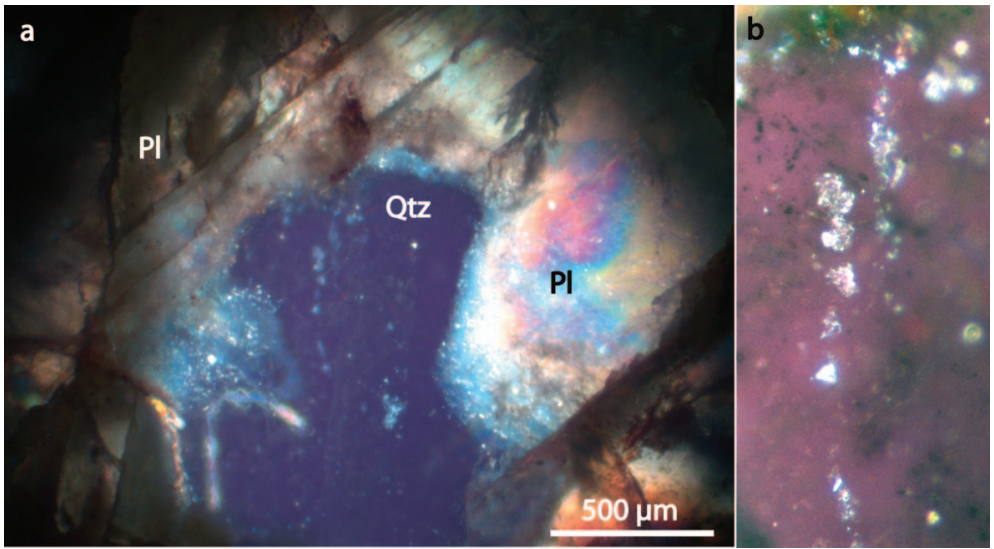

FIG. 10. (a) Replacement of plagioclase (Pl) by quartz (Qtz) in the graphic zone of the Rønne pegmatite by a nahcolite-rich solution. The bright tracks in quartz in the magnified image $(b)$ mark the original plagioclase by remnant feldspar and calcite. 
quartz- and alkali-carbonate-rich melt inclusions, which, by deposition of quartz on the inclusion wall during cooling, have been transformed from melt inclusions into apparent fluid inclusions (Fig. 8b). Using equation (1), 30 wt. $\%$ nahcolite corresponds to 21.5 wt. $\%$ $\mathrm{SiO}_{2}$. As these inclusions are present at an early stage of the Rønne pegmatite evolution, as indicated by the transfer of calcite into the wall zone of the host rock and by the high concentration of nahcolite-rich inclusions in quartz of the graphic zone, we can conclude that the primary pegmatite-forming melt was rich in alkali carbonates and water. Moreover, as we have also found coexisting aluminosilicaterich melt inclusions we can infer that these alkali carbonate-rich inclusions were formed as a result of a melt-melt-fluid immiscibility process from a primary water-rich and carbonate-bearing silicate melt.

At high temperatures a carbonate-rich fluid or water-rich melt can dissolve a large amount of $\mathrm{SiO}_{2}$. The HDAC experiments of Thomas et al. $(2006 ; 2011 b)$ show that such fluids promote the formation of $\mathrm{SiO}_{2}$ colloids. In such systems the alkalis remain in solution as ions, providing a simple mechanism for the strong separation of the silica gel. For example, Smirnov et al. (2012) showed experimentally that a minimum of $2 \mathrm{wt} . \%$ $\mathrm{Na}_{2} \mathrm{O}$ was required to produce a colloidal form of silica (a hydrosilicate liquid or HSL in their terminology), and that above that value the amount of HSL formed was proportional to the amount of $\mathrm{Na}_{2} \mathrm{O}$ present.

Mustart (1972) demonstrated a possible alternative to melt-melt-fluid immiscibility processes by using a hydrous albite and sodium disilicate melt as a model for peralkaline magmas. At temperatures $\leqslant 540^{\circ} \mathrm{C}$ and closed system conditions a fluid can contain 38 wt. $\% \mathrm{H}_{2} \mathrm{O}$ and continues to increase in $\mathrm{H}_{2} \mathrm{O}$ content to a maximum of $50 \mathrm{wt} . \%$ at $290^{\circ} \mathrm{C}$, at which point analcime begins to form at the expense of albite (Mustart, 1972: p. 116 and also summary on p. 126). Crystallization of albite produces an increase in the sodium disilicate and water concentrations in the melt and the dissolution of vapour. The water content can increase to very high levels (50 wt.\%) down to low temperatures $\left(<300^{\circ} \mathrm{C}\right)$ without formation of a vapour phase. This model should also be applicable nahcolite-bearing systems if alkali carbonate is used in place of sodium disilicate.
What is the source of the high alkali carbonate concentrations?

Previous studies have suggested the existence of a sol/gel state during pegmatite-forming processes (e.g. Brotzen 1959; Taylor 2005, 2006), but they have had little influence on recent pegmatite studies. We have found gel-like inclusions in several pegmatites or pegmatitic granites including those at: Borborema; Bornholm; Ehrenfriedersdorf; Königshain; Malkhan; Muiane; and Naipa, suggesting that they might be unrecognized rather than rare (Thomas and Davidson, 2008). A question which arises from the conclusions presented in this study, and those of Thomas et al. (2011a,b, 2012) and from Thomas and Davidson (2012a) is, where does the carbonaterich pegmatite-forming fluid come from?

The solubility of carbonate in silicate melts of typical granitic composition is very low and decreases with decreasing temperature (Sood, 1981; Liu et al., 2005). According to Sood (1981) the solubility of $\mathrm{CO}_{2}$ in a granitic melt is $2500-3500 \mathrm{ppm}$ at $1200^{\circ} \mathrm{C}$. At lower temperatures $\left(\sim 750^{\circ} \mathrm{C}\right)$ the solubility is only about $500 \mathrm{ppm}$.

As the Rønne granite is modally poor in carbonates, and their abundance near the pegmatite veins increases significantly, the alkali carbonates are clearly an important primary component of the pegmatite-forming system. Three different sources for alkali carbonates in the granite-pegmatite system can be considered First, the parental granite melt carried considerably more alkalis in proportion to alumina (cf. Tuttle and Bowen, 1958: p. 88-89) and therefore may have been saturated in carbonates at high temperatures, as indicated by the primary calcite crystals in feldspars. With cooling the alkali carbonates would strongly fractionate into the mobile pegmatite-forming system as a result of their differing solubilities in granitic and peralkaline pegmatite-forming fluids. The experimental work of Mustart (1972) is important in this respect as data for the system $\mathrm{Na}_{2} \mathrm{Si}_{2} \mathrm{O}_{5}-\mathrm{NaAlSi}_{3} \mathrm{O}_{8}-\mathrm{H}_{2} \mathrm{O}$ showed clearly that excess alkalis increase the maximum solubility of water and $\mathrm{CO}_{3}^{2-}$ significantly (Thomas and Davidson, 2012b). Secondly, it might be that during melting of nahcolite-rich sediments (Kempe and Degens, 1985) in the lower crust the granite-forming melt was enriched or saturated in alkali carbonates. Thirdly, the alkali carbonate-rich pegmatite-forming fluid originates directly from a $\mathrm{CO}_{2}$ metasomatized mantle source (Bonin, 2005; B. Bonin, pers. comm.). 
The data of table 2 in Noe-Nygaard (1963) show that the carbonate concentration at the granodiorite-pegmatite contact is 0.76 wt.\%, whereas in the granodiorite away from the contact the concentration is below the detection limit. The inference is that the high carbonate concentration is a direct result of transfer from the pegmatite. This conclusion is also consistent with the common observation of calcite crystals in the feldspars and quartz of the pegmatite and with the presence of nahcolite-rich fluid inclusions in quartz and the rarity or absence of these inclusions in the undisturbed rock.

According to McKenzie (1985) small amounts of carbonate-bearing melt can be effectively extracted from a bulk granite/granodiorite system because of its very low viscosity. For the separation and influx of a pegmatite-forming melt from the granodiorite matrix into the dilation veins the viscosity must be sufficiently low. Using the model of McKenzie (1985) this threshold viscosity is $10^{2} \mathrm{~Pa} \mathrm{~s}$ (Thomas and Davidson, $2012 a$ ). At $700^{\circ} \mathrm{C}$ this equates to a minimum water content of about $12.5 \mathrm{wt} . \%$. Further crystallization of quartz and K-feldspar will dramatically increase the water and carbonate content in the system, forming a low viscosity Na-alkaline carbonate fluid which can dissolve large amounts of $\mathrm{SiO}_{2}$. The excess alkalis and alkali carbonates prevent the formation of a vapour phase down to low temperatures, as indicated by the absence of miarolitic cavities in the Rønne pegmatite.

More problematically, if the source is according to the third hypothesis, fluids rich in alkali carbonates/bicarbonates would be expected outside of the alkali carbonate-rich pegmatitebearing granites. However, the reaction of such fluids with $\mathrm{Ca}^{2+}$-bearing fluids or rocks to produce calcite might mask their primary nature. Previous fluid inclusion studies (Newton et al. 1998) discussed only simple $\mathrm{CO}_{2}-\mathrm{H}_{2} \mathrm{O}-\mathrm{NaCl}$ fluids and might have led to an underestimation of the importance such carbonate-bearing fluids. Note that alkali carbonate-bearing or rich fluids would be excellent vehicles for the transport of alkalis and large ion lithophile elements upward through the crust.

\section{Implications of evidence of the high temperature formation of silica gels}

Evidence of the presence of silica gels at high temperatures demonstrates that at such temperatures high concentrations of alkali carbonates are not of only theoretical interest. However, current attention has focused on simple systems such as $\mathrm{CO}_{2}-\mathrm{H}_{2} \mathrm{O}$ or $\mathrm{CO}_{2}-\mathrm{H}_{2} \mathrm{O}-\mathrm{NaCl}$ with the low solubility capacity for aluminosilicate compounds. This is true not only of pegmatiteforming systems, as for example Smirnov et al. (2012) and Touret et al. (2007) have shown. Water-rich alkali-carbonate fluids have a high transport capacity for silica and numerous other molecules (Thomas et al., 2011a), a change into a sol/gel state would result in a separation of the alkalis from $\mathrm{SiO}_{2}$, producing, among other effects, almost pure $\mathrm{SiO}_{2}$ in pegmatite quartz cores. Moreover, the transport and extreme enrichment of $\mathrm{SiO}_{2}$ in large quartz veins no longer requires the so called "little red wagon effect" to deposit large quantities of silica from low solute-carrying capacity aqueous fluids, as discussed by London (2009).

The high concentrations of $\mathrm{Na}$ that are present when sol/gel forms can also serve as a source for the formation alkali-replacement minerals such as the saccharoidal masses of albite or cleavelandite (Brotzen, 1959) that are commonly found in pegmatites. For example, in cleavelandite from the Naipa pegmatite in Mozambique we have found direct evidence of a gel-like phase (Fig. 11), in addition to large and very flat (up to $200 \times 15 \times 3 \mu \mathrm{m})$ nahcolite-bearing $(8.3 \mathrm{wt} . \%)$ fluid inclusions.

In economic terms, the enrichment of $\mathrm{Li}$ in this stage might lay the foundations for the $\mathrm{Na}-\mathrm{Li}$ mineralization (Fig. 8b). Similarily, studies such as those of Smirnov et al. (2012) imply Ta might have high solubilities in alkaline gels or sodium silicate gels, with obvious applications to the formation of high field strength element and rare metal deposits, including the tantalite-type mineralization (Thomas et al., 2011a) that is commonly found in pegmatites.

\section{Conclusions}

Low temperature gel inclusions have been described in chalcedony and agate (Prokofiev et al., 2008). In this study of the pegmatites associated with the Rønne granodiorite, especially in the quartz-rich central parts of the pegmatite veins and their cores, we have found clear and surprising indications of former gel inclusions in both quartz and feldspars; these appear to represent the mineral-forming or re-forming medium at this stage. Furthermore, we have also found former gel inclusions in earlier-formed 


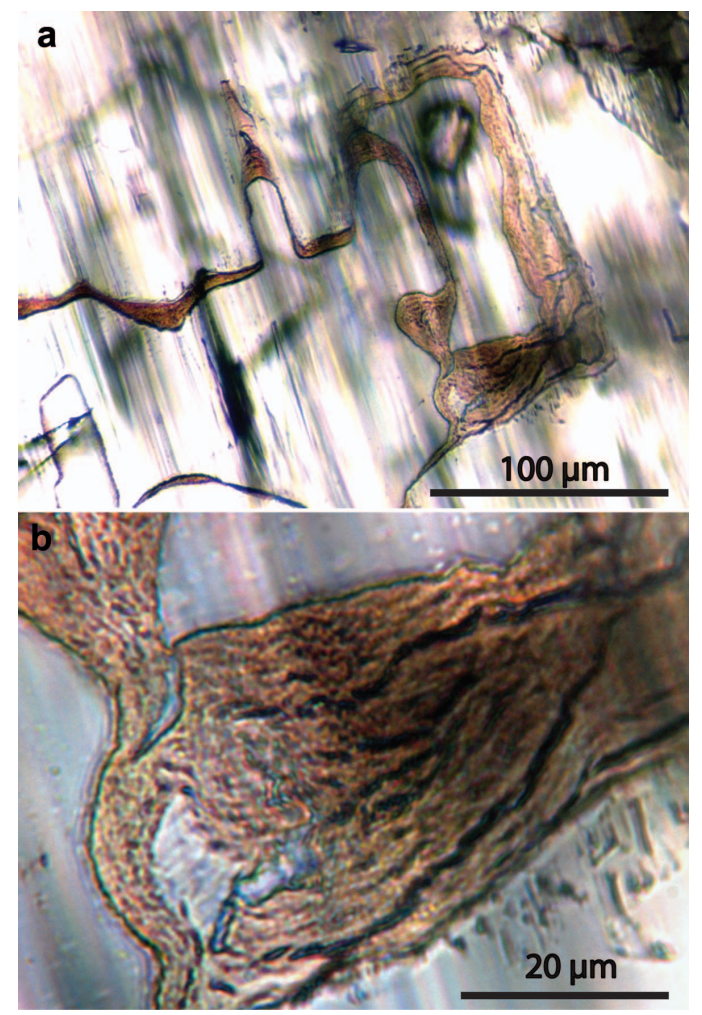

FIG. 11. (a) Cleavelandite from the Naipa pegmatite, Mozambique, showing a brownish pattern of gel inclusions. The photo $(b)$ is an enlargement of area above the scale bar in $(a)$.

quartz of the graphic granite zone, with a significant increase in the number of these inclusions in the direction of the quartz core, indicating the presence of high alkali and water concentrations at an early stage of pegmatite formation. The textural relationships of the former gel inclusions imply that the gel state was directly connected to the primary mineral-forming processes at temperatures from $\sim 700^{\circ} \mathrm{C}$ to $\sim 550^{\circ} \mathrm{C}$, and thus that the sol/gel phase is not of secondary post-magmatic origin. The coexistence of silicate melt inclusions with gel inclusions in some stages of the pegmatite formation does not imply that silicate sol/gel states are dominant in pegmatite formation, nonetheless the high water and alkali carbonate contents allow temporary transitions into this state. The high primary alkali carbonate contents of some pegmatites poses questions regarding the origin of these compounds, which require further studies using stable isotope methods.

In general terms, the addition of a possible sol/ gel state into discussions of pegmatite-forming processes widens its physical and chemical basis considerably. The interplay of these different processes enables the large variety in the appearance of pegmatites and their chemical, mineralogical and textural development, which commonly appear to be independent of the host rocks, to be better understood. The diversity of parameters such as temperature, pressure, concentration and speciation within wide limits differentiates the pegmatite-forming process from all other magmatic or hydrothermal processes.

\section{Acknowledgements}

The authors thank Prof. Peter Bankwitz for key samples from the Klippeløkkene quarry near Rønne, Bornholm Island, Denmark and Sergey Smirnov for his latest paper on hydrosilicate liquids. The manuscript benefitted from the constructive reviews by Tom Andersen and Axel Müller. The authors thank Roger Mitchell and David Green for copy editing the original manuscript.

\section{References}

Beyssac, O., Goffe, B., Chopin, C. and Rouzaud, J.N. (2002) Raman spectra of carbonaceous material in metasediments: a new geothermometer. Journal of Metamorphic Geology, 20, 859-871.

Bonin, B. (2005) The granite-upper mantle connection in terrestrial planetary bodies: an anomaly to the current granite paradigm? Lithos, 80, 131-145.

Brotzen, O. (1959) Outline of mineralization in zoned granitic pegmatites. Geologiska Föreningens Förhandlingar, 81, 1-98.

Christensen, M.K. and Zimmermann, H.D. (2004) Allanite-(Ce) in the granitic pegmatite of Rønne, Bornholm, Denmark. Journal of the Geological Society of Sweden, 126, 70-71.

Correia Neves, J.M. and Lopes Nunes, J.E. (1974) High hafnium members of the zircon-hafnon series from the granite pegmatites of Zambézia, Mozambique. Contributions to Mineralogy and Petrology, 48, 73-80.

Dörfler, H.-D. (2002) Grenzfächen und kolloid-disperse Systeme. Springer, Berlin, 989 pp.

Frondel, C. (1962) The System of Mineralogy of James Dwight Dana and Edward Salisbury Dana. Volume III, Silica Minerals. Seventh edition. John Wiley and Sons, New York and London, 334 pp. 


\section{R. THOMAS AND P. DAVIDSON}

Götze, J., Nasdala, L., Kleeberg, R. and Wenzel, M. (1998) Occurrence and distribution of "mogánite" in agate/chalcedony: a combined micro-Raman, Rietveld, and cathodoluminescence study. Contributions to Mineralogy and Petrology, 133, 96-105.

Jøgart, T. (2001) Bornholms Grundfjelds Geologi. Excursion guide, University Roskilde, Denmark, Publication 111, 1-38, [in Danish].

Kempe, S. and Degens, E.T. (1985) An early soda ocean? Chemical Geology, 53, 95-108.

Khakimov, A.K. (1968) Genetic types of inclusions of agate amygdales and veins of the Idzhebanskii deposit in Armenia. Pp. 230-236 in: Mineralogical thermometry and barometry. Volume II. New Methods and Results of Study of Parameters of Ore Formation. Nauka, Moscow, [in Russian].

Kingma, K.J. and Hemley, R.J. (1994) Raman spectroscopic study of microcrystalline silica. American Mineralogist, 79, 269-273.

Large, R.R. (1969) Review of Colloids in Ore Genesis. Unpublished honours thesis, University of Tasmania, Tasmania, Australia, 61 pp [http://eprints.utas.edu.au/11473/].

Liu, Y., Zhang, Y. and Behrens, H. (2005) Solubility of $\mathrm{H}_{2} \mathrm{O}$ in rhyolitic melts at low pressure and new empirical model for mixing $\mathrm{H}_{2} \mathrm{O}-\mathrm{CO}_{2}$ solubility in rhyolitic melts. Journal of Volcanology and Geothermal Research, 143, 219-235.

London, D. (2009) The origin of primary textures in granitic pegmatites. The Canadian Mineralogist, 47, 697-724.

McKenzie, D. (1985) The extraction of magma from the crust and mantle. Earth and Planetary Science Letters, 74, 81-91.

Merritt, C.A. (1923) The function of colloids in pegmatitic growth. Proceedings and Transactions of the Royal Society of Canada, XVII, 61-68.

Micheelsen, H.I. (1960) Pegmatites in the PreCambrian of Bornholm, Denmark. Report from the International Geological Congress, XXI Session, Norden, XVII, 128-136.

Müller, A. and Koch-Müller, M. (2009) Hydrogen speciation and trace element contents of igneous, hydrothermal and metamorphic quartz from Norway. Mineralogical Magazine, 73, 569-583.

Mustart, D.A. (1972) Phase relations in the peralkaline portion of the system $\mathrm{Na}_{2} \mathrm{O}-\mathrm{Al}_{2} \mathrm{O}_{3}-\mathrm{SiO}_{2}-\mathrm{H}_{2} \mathrm{O}$. Unpublished $\mathrm{PhD}$ Thesis, Stanford University, Berkeley, California, USA, $187 \mathrm{pp}$.

Newton, R.C., Aranovich, L.Y., Hansen, E.C. and Vandenheuvel, B.A. (1998) Hypersaline fluids in Precambrian deep-crustal metamorphism. Precambrian Research, 91, 41-63.

Noe-Nygaard, A. (1963) The Precambrian of Denmark. Pp. 1-25 in: The Precambrian. Volume 1 (K.
Rankama, editor). John Wiley, New York.

Prokofiev, V.Yu., Melnikov, F.P., Selector, S.L., Trubkin, N.V. and Andrusenko, N.I. (2008) Fluid inclusions with colloid solutions in chalcedony. Proceedings of the XIII International Conference on Thermobarogeochemistry and $I V^{\text {th }}$ APIFIS Symposium, 2, 125-128, [in Russian].

Rankin, A.H. and Le Bas, M.J. (1974a) Liquid immiscibility between silicate and carbonate melts in naturally occurring ijolite magma. Nature, 250, 206-209.

Rankin, A.H. and Le Bas, M.J. (1974b) Nahcolite $\left(\mathrm{NaHCO}_{3}\right)$ in inclusions in apatites from some E. African ijolites and carbonatites. Mineralogical Magazine, 39, 564-570.

Smirnov, S.Z., Thomas, V.G., Kamenetsky, V.S., Kozmenko, O.A. and Large, R.R. (2012) Hydrosilicate liquids in the system $\mathrm{Na}_{2} \mathrm{O}-\mathrm{SiO}_{2}$ $\mathrm{H}_{2} \mathrm{O}$ with $\mathrm{NaF}, \mathrm{NaCl}$ and Ta: evaluation of their role in ore and mineral formation at high $\mathrm{T}$ and $\mathrm{P}$. Petrologiya, 20, 300-314.

Sood, M.K. (1981) Modern Igneous Petrology. John Wiley \& Sons, New York, 244 pp.

Taylor, M.C. (2005) The sol-gel nature of pegmatites. Abstracts of the International Meeting on Crystallization Processes in Granitic Pegmatites, Elba, Italy.

Taylor, M.C. (2006) The gel model for the formation of gem-bearing pockets within granitic pegmatites, and implications for gem synthesis. Gems and Gemology, 42, 110-111.

Thomas, R. (1994) Thermometric study on granites from Bornholm island, Denmark. Zeitschrift für Geologische Wissenschaften, 22, 139-145.

Thomas, R. and Davidson, P. (2008) Water and melt/ melt immiscibility, the essential components in the formation of pegmatites; evidence from melt inclusions. Zeitschrift für geologische Wissenschaften, 36, 347-364.

Thomas, R. and Davidson, P. (2012a) Water in granite and pegmatite-forming melts. Ore Geology Reviews, 46, 32-46.

Thomas, R. and Davidson, P. (2012b) The application of Raman spectroscopy in the study of fluid and melt inclusions. Zeitschrift der Deutschen Gesellschaft für Geowissenschaften, 163, 113-126.

Thomas, R., Schmidt, C., Veksler, I., Davidson, P. and Beurlen, H. (2006) The formation of peralkaline pegmatitic melt fractions: evidence from melt and fluid inclusion studies. Estudos Geológicos, 16, $61-67$.

Thomas, R., Davidson, P. and Beurlen, H. (2011a) Tantalite-(Mn) from the Borborema pegmatite province, northeastern Brazil: conditions of formation and melt- and fluid-inclusion constraints on experimental studies. Mineralium Deposita, 46, 
$749-759$.

Thomas, R., Davison, P. and Schmidt, C. (2011b) Extreme alkali bicarbonate- and carbonate-rich fluid inclusions in granite pegmatite from the Precambrian Rønne granite, Bornholm Island, Denmark. Contributions to Mineralogy and Petrology, 161, 315-329.

Thomas, R., Davidson, P. and Beurlen, H. (2012) The competing models for the origin and internal evolution of granitic pegmatites in the light of melt and fluid inclusion research. Mineralogy and Petrology, 106, 55-73.

Thomas, S.-M., Thomas, R., Davidson, P., Reichart, P., Koch-Müller, M. and Dollinger, G. (2008) Application of Raman spectroscopy to quantify trace water concentrations in glasses and garnets. American Mineralogist, 93, 1550-1557.

Thomas, S.-M., Koch-Müller, M., Reichart, P., Rhede, D., Thomas, R., Wirth, R. and Matsyuk, S. (2009) IR calibrations for water determination in olivine, $\mathrm{r}$ $\mathrm{GeO}_{2}$, and $\mathrm{SiO}_{2}$ polymorphs. Physics and Chemistry of Minerals, 36, 489-509.

Touret, J.L.R., Smirnov, S.Z., Peretyazhko, I.S., Zagorsky, V.Y. and Thomas, V.G. (2007) Magmatic-hydrothermal transition in tourmalinebearing miarolitic pegmatites: Hydrosaline fluids or silica gels? Pp. 92-93 in: Granitic Pegmatites: The State of the Art (T. Tartins and R. Vieira, editors). Memorias, 8. Departamento de Geologia, Universidade do Porto, Portugal.

Tuttle, O.F. and Bowen, N.L. (1958) Origin of granite in the light of experimental studies in the system $\mathrm{NaAlSi}_{3} \mathrm{O}_{8}-\mathrm{KAlSi}_{3} \mathrm{O}_{8}-\mathrm{SiO}_{2}-\mathrm{H}_{2} \mathrm{O}$. Geological Society of America Memoir, 74. The Geological Society of America, Boulder, Colorado, USA, 153 pp.
Upton, B.G.J., Hill, P.G., Johnsen, O. and Petersen, O.V. (1978) Emeleusite: a new $\mathrm{LiNaFe}^{\mathrm{III}}$ silicate from south Greenland. Mineralogical Magazine, 42, $31-34$.

Veksler, I.V. and Thomas, R. (2002) An experimental study of B-, P- and F-rich synthetic granite pegmatite at 0.1 and $0.2 \mathrm{GPa}$. Contributions to Mineralogy and Petrology, 143, 673-683.

Veksler, I.V., Thomas, R. and Schmidt, C. (2002) Experimental evidence of three coexisting immiscible fluids in synthetic granite pegmatite. American Mineralogist, 87, 775-779.

Waight, T.E., Frei, D. and Storey, M. (2012) Geochronological constraints on granitic magmatism, deformation, cooling and uplift on Bornholm, Denmark. Bulletin of the Geological Society of Denmark, 60, 23-46

Walrafen G.E. and Douglas, R.T.W. (2006) Raman spectra from very concentrated aqueous $\mathrm{NaOH}$ and from wet and dry, solid, and anhydrous molten, $\mathrm{LiOH}, \mathrm{NaOH}$, and KOH. Journal of Chemical Physics, 124, http://dx.doi.org/10.1063/1.2121710.

Wilkinson, J.J., Nolan, J. and Rankin, A.H. (1996) Silicothermal fluid: a novel medium for mass transport in the lithosphere. Geology, 24, 1059-1062.

Williamson, B.J., Wilkinson, J.J., Luckham, P.F. and Stanley, C.J. (2002) Formation of coagulated colloidal silica in high-temperature mineralizing fluids. Mineralogical Magazine, 66, 547-553.

Zariňš, K. and Johansson, ̊. (2009) U-Pb geochronology of gneisses and granitoids from the Danish island of Bornholm: new evidence for 1.47-1.45 Ga magmatism at the southwestern margin of the East European Craton. International Journal of Earth Sciences, 98, 1561-1580. 
